\title{
MUTUAL HELP GROUP FOR FAMILY MEMBERS OF OLDER ADULTS WITH DEMENTIA: UNVEILING PERSPECTIVES ${ }^{1}$
}

\author{
Fernanda Rosa de Oliveira Pires², Silvia Maria Azevedo dos Santos³, Ana Lúcia Schaefer Ferreira de Mello", \\ Kelly Maciel Silva
}

\footnotetext{
${ }^{1}$ Article extracted from the thesis - Mutual Help Group for family members of older adults with dementia: a space of dialogue and significance, presented to the Programa de Pós-Graduação em Enfermagem (PEN), Universidade Federal de Santa Catarina (UFSC), in 2015.

${ }^{2}$ M.Sc. in Nursing, PEN/UFSC. Florianópolis, Santa Catarina, Brazil. E-mail: nandadode@hotmail.com

${ }^{3}$ Ph.D. in Education. Professor, Nursing Departament, PEN/UFSC. Florianópolis, Santa Catarina, Brazil. E-mail: sazevedoms@ gmail.com

${ }^{4}$ Ph.D. in Nursing and Dentistry in Collective Health. Professor, Dentistry Departament, UFSC. Florianópolis, Santa Catarina, Brazil. E-mail: alfm@terra.com.br

${ }^{5}$ Doctoral student, PEN/UFSC. Nurse Family Health Strategy of the Municipality of Florianópolis. Florianópolis, Santa Catarina, Brazil E: mail: kellymacielsilva@yahoo.com.br
}

\begin{abstract}
Objective: to understanding the reasons why members of a Mutual Help Group for family caregivers of older adults with Dementia participate in it and to identify the difficulties and benefits of such participation.

Method: a qualitative exploratory descriptive study with data collected through observation and interviews with nine family caregivers, five family volunteers and five health professionals from the group. Data analysis involved content analysis and theoretical support of the Cultural Care Theory.

Results: the respondents pointed out their reasons for seeking the group and the benefits they perceived from participating in it. However, difficulties to participate continuously in the group faced by both family caregivers and volunteers were also evidenced. Nontheless, all of them valued the possibility of being part of this group.

Conclusion: the Mutual Help Group has proven to be an important supportive strategy for family caregivers of older adults with dementia, however, much remains to be done in order to make this strategy feasible for all families. Among the difficulties identified for maintaining the group are voluntary work and a way to attract more people to this work.
\end{abstract}

DESCRIPTORS: Self-help groups. Nursing. Dementia. Caregivers. Volunteers.

\section{GRUPO DE AJUDA MÚTUA A FAMILIARES DE PESSOAS IDOSAS COM DEMÊNCIA: DESVELANDO PERSPECTIVAS}

\section{RESUMO}

Objetivo: compreender os motivos pelos quais os integrantes de um Grupo de Ajuda Mútua a cuidadores familiares de pessoas idosas com Demências participam do mesmo e identificar as dificuldades e os benefícios dessa participação.

Método: pesquisa qualitativa exploratória descritiva, cujos dados foram coletados por meio de observação e entrevistas com nove cuidadores familiares, cinco familiares voluntários e cinco profissionais da saúde integrantes deste grupo. A análise dos dados envolveu a análise de conteúdo e suporte teórico da Teoria do Cuidado Cultural.

Resultados: os informantes apontaram os motivos para buscar o grupo e os benefícios que percebiam a partir de sua participação no mesmo. No entanto, as dificuldades para participar continuamente do grupo, enfrentadas tanto pelos cuidadores familiares como pelos voluntários, também foram evidenciadas. Porém todos eles valorizaram a possibilidade de fazer parte desse grupo.

Conclusão: o Grupo de Ajuda Mútua revelou-se uma importânte estratégia de suporte para cuidadores familiares de idosos com demência, no entanto, muito ainda há para ser feito a fim de tornar essa estratégia viável a todas as famílias. Entre as dificuldades apontadas para manutenção do grupo é o trabalho voluntário e a forma de atrair mais pessoas para esse trabalho.

DESCRITORES: Grupos de autoajuda. Enfermagem. Demências. Cuidadores. Voluntários. 


\section{GRUPO DE AYUDA MUTUA A FAMILIARES DE ADULTOS MAYORES CON DEMENCIA: REVELANDO PERSPECTIVAS}

\section{RESUMEN}

Objetivo: comprender los motivos por los cuales los integrantes de un Grupo de Ayuda Mutua a cuidadores familiares de adultos mayores con demencia participan del mismo e identificar las dificultades y los beneficios de esta participación.

Métodos: investigación cualitativa, exploratoria y descriptiva, cuyos datos fueron recolectados por medio de observación y entrevistas con nueve cuidadores familiares, cinco familiares voluntarios y cinco profesionales de salud integrantes de este grupo. El análisis de los datos envolvió el análisis de contenido y el soporte teórico surgió de la Teoría del Cuidado Cultural.

Resultados: los informantes apuntaron los motivos para buscar el grupo y los beneficios que percibían a partir de su participación en el mismo. Sin embargo, las dificultades para participar continuamente tanto por los cuidadores familiares como por los voluntarios, también fueron evidenciadas. Además, todos ellos valorizaron la posibilidad de formar parte del grupo.

Conclusión: el grupo de ayuda mutua reveló una importante estrategia de soporte para los cuidadores familiares de adultos mayores con demencia, sin embargo, hay mucho que hacer aun para tornar esta estrategia viable para todas las familias. Entre las dificultades apuntadas para el mantenimiento del grupo es el trabajo voluntario y la forma de atraer más personas para este trabajo.

DESCRIPTORES: Grupos de autoayuda. Enfermería. Demencia. Cuidadores. Voluntarios.

\section{INTRODUCTION}

Mutual Help Groups (MHGs) are made up of people who share similar life problems such as the traumatic events of chronic, disabling and disabling diseases. In these groups, people who experience the same experiences develop an ability to listen attentively and with interest, they exercise a capacity for mutual help, they seek knowledge about their health problem, and they develop a sense of belonging. Participating in such groups is important for strengthening the members' self-esteem and selfconfidence, as well as reducing isolation by favoring social insertion and coexistence with a chronic condition. Each group has their own characteristics of structure, interaction, union, social identity and objectives which form the individual patterns and values of the group. ${ }^{1-2}$

The long time of use of MHG care technology can be highlighted, especially by nurses who, along with the multidisciplinary team, provide care for dependents and their family members, becoming a strategy for family (re)organization. ${ }^{3-4}$

Studies have revealed significant effects of MHGs on family caregivers' knowledge, skills and well-being, as well as relief from burnout/overload, and although their effectiveness is inferior to multicomponent training, it is still an effective and low-cost intervention. ${ }^{5-6}$

It is important to pay attention to the health not only of the person affected by dementia, but also of their family caregivers. In the context of caring for relatives of people with dementia, there are already different interventions such as case counseling/management, psychoeducational groups, psychotherapeutic approaches, multicomponent approaches and MHGs. ${ }^{7}$
Although the MHG is portrayed as an important methodology for caring for the families of older adults with dementia, the literature points out that the number of family members seeking this care fluctuates from one encounter to another. ${ }^{8}$

These concerns are reflected in Madeleine Leininger's Theory of Cultural Care, and gave rise to the following research question: what are the motives/ reasons, benefits and difficulties uncovered in this cultural context of care that lead family members of older adults with dementia to be part of this group?

Thus, the purpose of this article is to understand the reasons why the members of an MHG for family caregivers of older adults with dementia, from the municipality of Florianópolis-SC, participate in it and identify the difficulties and benefits of this participation.

\section{METHOD}

The present study adopted a qualitative, exploratory-descriptive approach. The place chosen to carry out the research was a MHG for families caring for older adults with Alzheimer's Disease and/or similar diseases in the municipality of Florianópolis-SC.

MHG was created in 1994, and since 2004 it has been formally recognized as the Brazilian Regional Association of Alzheimer's in Santa Catarina (ABRAZ-SC). Through this partnership, the support work was extended to families caring for older adults with dementia in the interior of the State, and at the time of the study there were 10 Sub-regional ABRAZSC that attended about 1,500 families a month. ${ }^{9}$

Nineteen (19) people, including nine family caregivers, five family volunteers and five professionals who contribute to the development of the 
Group's activities participated in this study. The difference between caregiver-relatives and family volunteers is in the form of participation in the group. Family caregivers are those who are in the group to learn how to deal with the present care situation in dementia. On the other hand, the family volunteer is in the group to assist in its operation and to share experiences of when they were responsible for caring for a family member with dementia.

The selection of family caregiver participants was intentional and followed the following inclusion criteria: having at least three months of participation in the Group and minimum age of 18 years. For professionals and volunteers, the inclusion criteria was a minimum age of 18 years and having at least one year working experience in the Group.

Data collection took place between September and December 2014 through techniques of nonparticipant observation of four MHG meetings and individual semi-structured interviews with each of the respondents.

During the meetings, the following were perceived: developed expressions and actions, the place description, the participants' postures, and the topics discussed, in addition to any information, characteristics, phenomena or events that had any explicit or implicit meaning related to the purpose of the study. These observations served as a guideline to the researcher both during the interview script formulation and in describing the research results, helping her return to the collection moment and to relive the experience in the search for meanings.

After completing the observation phase, the researcher scheduled the date, time and place of preference of each participant to carry out the interview, and most of the interviewees chose their own homes. The interviews lasted from 45 to 60 minutes, and followed a semi-structured script formulated by the researcher according to observations made in the Group and aligned with the Cultural Care Theory. ${ }^{10}$

The interviews as well as the notes of the researcher were transcribed onto a Microsoft Word ${ }^{\circledR}$ program file for data organization. The data were transferred to Atlas.ti ${ }^{\circledR}$ data organizer version 7.5.4, creating a new hermeneutic unit. ${ }^{11}$ Respondents were identified as family caregivers (FC), family volunteers (FV) and professional volunteers (PV), along with the number corresponding to the insertion sequence in the program (FC1, FC2...FC9; FV1, FV2...FV5; PV1, PV2...PV5). Field diaries were transcribed as memos of the hermeneutical unit.

The steps recommended by content analysis were used for data analysis, ${ }^{12}$ namely: pre-analysis; material exploration; inference and understanding. Three main thematic axes were reached at the end of the analysis. However, only thematic axis 1 will be presented in this article, which contemplated motivations for participation in the MHG, along with the difficulties and benefits of participation.

The research project was submitted to the Research Ethics Committee of the Universidade Federal de Santa Catarina and approved by Certificate of Presentation for Ethical Appreciation (CAAE) under no. 32996214.6.0000.0121. This study respected the ethical precepts of voluntary participation, clarified and consented under Resolution 466/12, which governs research on human beings in Brazil. The signing of the Free and Informed Consent Form was requested by the researcher both in carrying out observations in the Group's meetings and for the individual interviews.

\section{RESULTS}

Analysis of the collected data made it possible to understand the perspectives of the MHG members for familiar caregivers of older adults with dementia in Florianópolis, based on the thematic axis Mutual Help Groups: unveiling perspectives. Therefore, the following categories will be presented: Reasons for seeking the group; Benefits of group participation; Difficulties of getting involved in the group; and Valuing being in the group.

\section{Reasons for seeking the group}

In this category, the members revealed what led them to participate in the MHG, highlighting their search for care knowledge, listening and sharing experiences, helping others and performing voluntary work as motivating factors, and can be observed in the testimonials below:

[...] I came to the group seeking more knowledge about the disease, the care, the anguish we feel without having answers to the questions (FV4); I see that sometimes simple guidelines, which I deem simple, I share with the families and it is as if it solved their lives. [...] now I really feel that I'm helping people, I'm motivated (PV4).

In addition to these motivating factors, some members of this research emphasized that participating in the group was a way of compensating for what they could not do for a relative of their own, a motivation not reported in previous studies, as described in the following statements:

[...] at the time I could not do anything for her, it's as if I had a debt ... but now I'm trying to do it for others, 
a feeling of retribution. [...] when I came to the group, she had already died (FV5); the group was very important to me because I needed the group, even to to alleviate some my guilt for not living closer [to him/her] [...] (PV1).

\section{Benefits of group participation}

The feeling of satisfaction in helping another brought a sense of well-being, and at the same time allowed family caregivers and volunteers to reflect on their condition relative to other family members in order to see their reality from a new perspective. The prospect of not being the only one facing difficult situations and that care circumstances previously experienced by another and surpassed could be somebody else's challenge.

In addition to personal reflection on problems, professional volunteers mentioned the recovery of attentive and qualified listening as another benefit of participation in the group, as exemplified by the following excerpts:

today what helps me is this feeling of knowing that I am helping other people just as I was helped, I feel satisfied. [...] it's a benefit, it gives me a feeling of wellbeing (FV4).

Participating in the Group provided meaningful knowledge about dementia, knowing how to handle the older adult in this condition, strengthening the caregivers' feelings about this situation, and the importance of self-care.

MHG has helped me to understand the evolution of knowledge regarding the disease and to strengthen our feelings, even knowing when to be energetic and when to give in ... the exchange of experiences ... all this I learned there (FC8).

The study group was defined as a therapeutic space in the reports of some participants, and this characteristic was attributed to it by the possibility of free expression of emotions and feelings, with the certainty of being understood and not judged by the relation of trust and by the construction of true bonds between members of the Group. We also emphasize the welcoming, attentive and interested listening as beneficial elements of the participation in the group, as mentioned in the highlighted speeches:

I think the group works more as a therapy, after we started participating (FC5); Although this is not the proposal of a therapeutic group, many family members see the support group as their therapy because their anxiety is worked out (FV4).

Another aspect highlighted by relatives was the possibility that they learned or improved strat- egies in the MHG to facilitate managing family members with dementia, as evidenced in the following statements:

[...] I used to insist/argue with her to go take a shower, she would get irritated. I thought that this is not right, now I don't insist anymore, I wait a while and I try again. We learn as we go, I heard here in the group that it was easier to do it this way (FC6).

\section{Difficulties of getting involved in the group}

When speaking about the group, the members revealed situations that undermine their greater involvement with it. Among the situations pointed out by family caregivers was the change in the health status of their relatives with dementia, such as the occurrence of urinary infection, pneumonia and falls. Moreover, they reported that they could not leave their relatives with dementia alone, and had other personal demands that made them prioritize meeting their commitments. The difficulty of dealing with the loss of a loved one to whom they devoted so much time of care was also mentioned as an obstacle for them to continue being involved with the group.

I go there [to the MHG], but there are times when I'm still not with my foot well on the ground [I don't feel like I'm totally there/present], I was accustomed to having to deal with him [my spouse who had dementia]. But I want to go to the volunteer group. (FC1).

Volunteers revealed limiting situations to volunteer work, such as management of the demands of extra MHG activities, the small number of volunteers to divide the tasks, the turnover of volunteers, the need for experience and affinity with the theme of "dementia" to mobilize and retain new volunteers:

\section{[...] we are looking for more members, encouraging} (people). We need to add more people to the group, and it can't be just anyone, it has to be someone who understands a little, someone who really likes it, someone who has the disposition (FV3).

The MHG members of the study pointed out the lack of relationship outside the group space as a difficulty. Some still reflect that this lack of relationship prevents them from knowing and helping each other in greater depth in group meetings and affirming a desire to overcome this barrier.

A few professionals reported that at the beginning of the MHG, they used to visit family caregivers, but currently, with the exception of a few isolated visits, they only communicate through facebook, as exemplified in the following statements: 
[...] I have no friendship outside the group [with MHG members] (FV3); I've had relationships with people outside the group. I remember a time we used to visit a lady of the group quite often. Currently, the group no longer makes these visits. But I still keep in touch (with her) on facebook to this date and with two other caregivers, a while ago I met her for coffee (PV1).

\section{Valuing being in a group}

Being in a group is recognized by the participants as a positive and differentiated experience in caring for family members, a condition that allows one to approach and recognize oneself in the situation of the other. This finding seems to amplify and enhance the professional's role in the health of the family caregiver by opportunizing a space for dialogue between the family and the professional, favoring to report problems, difficulties and limitations in care for him. The following lines give support in this category:

as much as literature says something, I still think this practice here [MHG] is a thousand times better than just reading. Paper has no feeling, it is theoretical. Literature speaks in a linear way, learning is different (FC2); I went online and researched everything I could, but after joining the group it all became clearer to me (FC7).

The satisfaction of belonging to MHG appeared in reports that identified it as support in the task of caring for an older adult with dementia.

The most important thing here [in the MHG] is to not fail in giving care, support, an ear to the family members. We can't lose the focus of the support group, (which lies) in the families (FV4).

Another value revealed in the cultural context of the MHG was the feeling of commitment to the group: the members value it as a work space in helping caregivers.

[...] I'm always there [at the MHG] I like that. We help those who need it most [the MHG]. It is not leisure, it is work, serving others, a humanitarian service (FV2); what motivates us is the commitment that we [MHG] have, I see the importance of people having this support (PV5).

\section{DISCUSSION}

Participation in the group motivated by the search for knowledge of dementia was revealed in other studies with support groups for relatives with dementia. ${ }^{13-15}$ Another important aspect of the search for groups is the opportunity for participants to listen to one another's experiences, and to organize themselves better in the face of the daily transformations caused by dementia. ${ }^{14-16}$
In general, the narratives/speeches of the family caregivers described the search for knowledge about the disease as motivation to participate in the group, which is attested to in practice by the MHGs serving as a reference for the propagation of knowledge about the pathologies and their progressions. Thus, the reports of this study corroborate with what was already evidenced in a previous study with family caregivers of people with Alzheimer's disease; when the caregiver is informed about the aspects of the disease, it becomes easier to provide satisfactory and quality care to the person with Dementia, and it is important to reinforce the investment in educational guidance strategies for caregivers. ${ }^{4}$

Some of the MHG members reported using the learnings they received in the Group to inform other family members. This finding corroborates members' speeches from other MHGs, where members passed on group learning to family, friends and organizations in order to raise awareness and reduce the stigma. ${ }^{17}$

Among the motivations pointed out, the desire to perform volunteer work was mentioned. A study carried out with MHG coordinators for family caregivers of people with dementia described previous experience in help groups, their desire to share with new caregivers their personal experiences, as well as personal benefits to volunteers as being motivations to exercise voluntary work. ${ }^{8}$

The participants emphasized the learning developed from the experience in the Group as a benefit of the participation. Learning related to the way of dealing with family members with dementia, with explanations related to dementias, self-care, and to the care of the family member with dementia.

A study with MHG revealed that many participants described how knowledge exchanges and experiences in the group helped them rebuild their lives, acknowledging themselves in the experience of others. ${ }^{17}$

Similar data were found in a study performed with participants of an MHG for relatives of people with Parkinson's disease, in which the participation in the group was highlighted as a beneficial experience due to the participants helping each other, creating a social support network. ${ }^{18}$ This positive experience meets the findings reported by participants from other Mutual Help Groups who reported having become more confident and informed in dealing with their problems and in understanding the treatment from their experiences in the MHG. ${ }^{17}$

In relation to the learning experience reported by relatives and professional volunteers, one can 
perceive a horizontal construction of knowledge, breaking from the hierarchy of biomedical power. This shows the participation in the group as a process of collective knowledge construction. ${ }^{16}$ In this sense, Leininger emphasizes in his Theory the need to look for culturally sensitive care, meaning without imposing knowledge of the professional culture in disrespecting what the other brings. ${ }^{10}$

A case study with a family caregiver of older adults with Alzheimer's disease concluded that to care for an older person with this pathology, the caregiver needs to develop patience, and MHGs are indicated as social support for family caregivers and people with this disease. ${ }^{20}$

In the present study, the MHG was characterized as a therapeutic space. Contrasting this finding, literature identifies that MHGs are not therapy groups. However, the researchers noted the presence of some therapeutic group factors; among them, the idea of caregivers sharing similar situations, helping others, creating an atmosphere so that caregivers feel confident to express themselves and respect them if they do not want to. In addition to these, they emphasized support, self-revelation and learning as therapeutic group factors. ${ }^{18}$

These findings are articulated with the results of a study that points to MHG as being a space for its members to reflect on different ideas, develop confidence, and feel able to share their situations. Participants in these MHGs report that there is a relationship of confidence in the group and that they believe that no one will leave and tell/spread what has been shared in the group to others. ${ }^{8}$

In nurses' reports on their experience in implementing a family caregivers support group for older adults with dementia and depression, stemming from the difficulties of caregivers in caring for older adults, the need for caregivers to share examples of daily care experiences in order to exchange experiences and facilitate management with older adults can be highlighted. ${ }^{20}$

Considering the benefits of participation in the MHG, it is inferred that this has contributed to the health and well-being of its members. According to the Cultural Care Theory, "health is defined as being well to maintain and help enable individuals or groups to carry out their daily activities, culturally expressing their care values and their lifestyles". ${ }^{10: 11}$ MHG facilitates the learning of collective strategies, however, regarding care for older adults with dementia who rely on them, it is important to consider them as unitary, individual human beings whose dignity must be respected.
When speaking about the group, the members revealed situations that undermine their greater involvement with it; among the difficulties pointed out by the group members, whether being relatives or professionals considered caregivers, we can highlight having to juggle different responsibilities in order to be present and involved in the MHG. This difficulty corroborates the discussion about the influence of development and progress that has occurred in the world during the last century, leading to changes in the social structures of families. Extended families were, almost in their entirety, replaced by nuclear families, resulting in an increase in multigenerationality in the households. In this way, potential caregivers accumulate roles and take on various tasks related to the household and family. ${ }^{21}$

Similarly, another study with caregivers of older adults with dementia reveals the occurrence of comorbidities in the family of the dementia patient which interferes with family dynamics, causing even more difficulties in performing care. ${ }^{2}$

We highlight that the focus of this research was an MHG developed by relatives and health professional volunteers in partnership with a nonprofit organization, which meets in a space provided within a public hospital. However, the Brazilian Unified Health System advocates that health care actions to family caregivers occur in the communities, based on the work of the Family Health Strategy teams, and in a decentralized manner. In this sense, we question the lack of a health support network in order to expand MHG care technology to the communities, guaranteeing access to family caregivers closer to their homes. ${ }^{22}$

A study with volunteer coordinators of the MHG pointed out that the frequency of participants is very variable in the meetings, together with low entry of new members and participation abandonment in the group by some relatives. The coordinators revealed that they still had the feeling that it was always the same few people who worked in the group. ${ }^{8}$

In the present study, there were no possible reasons for abandoning the group, but the number of participants participating in the meetings and the lack of more people involved in task division were mentioned; also, the recruitment of new volunteers is complex, due to the specificity of the work which requires some prior knowledge about dementia or at least, a desire to study the subject, a willingness to work with mutual help groups and availability of time to devote to this work.

In a study with MHG in the United Kingdom, the coordinators reported a feeling of unease about 
their condition in the group, as they did not have volunteers to help with their assignments, they complained about the lack of relationship between the MHGs, weak dissemination of each other's work as a hindering factor for recruiting new members to the group and weak support from health professionals. ${ }^{17}$

Participants in another study with MHG pointed to isolation as a consequence of coping with serious life-threatening or chronic diseases: MHGs were the place where they socialized with people who lived similar situations to themselves in order to feel less isolated and more hopeful. Many of these participants exchanged messages via facebook and phone, as well as meeting for a chat, a walk or to travel. ${ }^{17}$

The perceptions of family caregivers' experiences of people with dementia are ambiguous; at the same time that the caregiver lives the current experience, they deal with the reflection of experiences they have already experienced and with perspectives of what they would like to live. ${ }^{23}$ In this sense, we noticed that the members of the studied MHG exposed the difficulties of having a relationship among themselves outside the group space, but they reflected on the perspective of changing this condition, demonstrating the value of being in a group.

In a study in the same context of the present research, the authors revealed that the knowledge exchange in the MHG reduces heterogeneity between the participants who are actively involved in the discussions. Family members share their life experiences and the professionals reedit this experience, strengthening it with scientific knowledge, making the MHG a potential space for learning. ${ }^{24}$

MHG is a space where family caregivers expose their problems, share solutions and responses to the experiences they suffer, reframe their ways of perceiving the care given to the family member with dementia and build new relationships. In addition, MHG is a space where the family caregiver experiences helping other caregivers, increasing their selfesteem and their feeling of belonging to this group. ${ }^{24}$

The perspectives revealed in the category valuing the group by the members of the MHG corroborate the fundamental objectives of the MHGs described in the literature, namely: providing information about the disease and its evolution, providing resources and advice derived from the care experience of other participants, and providing support to understand how the MHG is achieving its care goals. ${ }^{19}$ Other researchers have also found value in being together due to the care received and the possibility of conversing with people in similar situations. ${ }^{16-18}$
In analyzing the reports of the members of this research in comparison to other MHGs described in the literature, we highlight many similarities and some differences. Discovering these relations of similarities and differences which are characteristics of a particular cultural context is essential for practicing culturally meaningful, therapeutic, congruent, and safe care. ${ }^{10}$

The study showed a limitation in the participants of the research, since they did not include people who had already attended the MHG and who, for some reason, had stopped attending. Such inclusion could lead us to understand their reasons for quitting the Group, reinforcing understanding of the factors that involve participation in an MHG. Another limiting factor was that this was an exploratory study carried out in only one MHG for family caregivers of older people with dementia.

\section{CONCLUSION}

According to the reports of MHG members, the group was perceived as a learning space, not only in relation to dementia, but also in the exercise of listening to others and reflecting on their own experiences, in addition to developing new strategies for dealing with the affected family member; as a therapeutic space, where it is possible to talk about feelings arising from the confrontations of daily care; as a horizontal space of dialogue between the family and the professional in a process of collective knowledge construction; and as a voluntary work space toward the service of others. The MHG member reports showed the importance of this participation, not only for family caregivers but also for professionals, in reaffirming the care for the older adult with dementia.

However, disclosure of situations that undermine greater involvement in the Group appeared strongly in the data of this study. This was evidenced by the lack of a network of social and health support for the family caregivers to gain access to the MHG. It is known that this group support strategy is feasible to be developed by Basic Unified Health System, however, it still does not present itself effectively and consistently in our reality.

On the other hand, it is believed that the study brings contributions to the overall knowledge about MHGs for family caregivers of older people with dementia. These contributions extend to nursing professionals and other disciplines interested in gerontology. From these results, it is also possible to perceive MHGs as a cultural care environment with their own 
values that need to be identified and adapted to provide culturally congruent care directed to the needs of relatives of older adults with dementia.

Finally, it also points out new possibilities for research in the context of MHG, not only involving family caregivers but also volunteers, including the search for partnerships and new strategies aimed at strengthening this care modality for people who care for older adults with dementia.

\section{REFERENCES}

1. Melo ASE, Maia Filho ON, Chaves HV. Conceitos básicos em intervenção grupal. Encontro: Revista de Psicologia [Internet]. 2014 [cited 2016 May 17]; 17(26):47-63. Available from: http:/ / pgsskroton.com. $\mathrm{br} /$ seer/index.php/renc/article/view/2414/2316

2. Alvarez AM, Gonçalves LHT, Schier J,Hammerschmidt KSA, Souza BC, Valcarenghi RV. Grupo de apoio às pessoas com doença de Parkinson e seus familiares. Extensio: Rev Eletr de Extensão [Internet]. 2016 [cited 2016 May 17]; 13(22):92-101. Available from: https:/ / periodicos.ufsc.br/index.php/extensio/article/ view/1807-0221.2016v13n22p92/31719

3. Ilha S, Backes DS, Backes MTS, Pelzer MT, Lunardi VL, Costerano RGS. (Re)organização das famílias de idosos com Alzheimer: percepção de docentes à luz da complexidade. Rev Esc Anna Nery [Internet]. 2015 [cited 2016 May 17]; 19(2):331-7. Available from: http:/ / www.scielo.br/scielo.php?script=sci_ arttext\&pid=S1414-81452015000200331

4. Santana RF, Almeida KS, Savoldi NA. Indicators of the applicability of nursing instructions in the daily lives of Alzheimer patient caregivers. Rev Esc Enferm USP [Internet]. 2009 [cited 2015 Apr 10]; 43(2):459-64. Available from: http:/ / www.scielo.br/pdf/reeusp/ v43n2/a28v43n2.pdf

5. Chien LY, Chu H, Guo JL, Liao YM, Chang LI, Chen $\mathrm{CH}$, et al. Caregiver support groups in patients with dementia: a meta-analysis. Int J Geriatr Psychiatry [Internet]. 2011 [cited 2015 Apr 10]; 26(10):1089-98. Available from: http://onlinelibrary.wiley.com/ doi/10.1002/gps.2660/epdf

6. Schuz B, Czerniawski A, Davie N, Miller L, Quinn MG, King C, et al. Leisure time activities and mental health in informal dementia caregivers. Appl Psychol Health Well Being [Internet]. 2015 [cited 2016 May 6]; 7(2):230-48. Available from: http:/ / onlinelibrary. wiley.com/doi/10.1111/aphw.12046/epdf

7. Alzheimer's Association. 2014 Alzheimer's disease facts and figures. Alzheimers Dement. 2014 Mar;10(2):e47-92.

8. Jerez CH, López MC. Caracterización de los grupos de ayuda mutua para cuidadores de familiares enfermos de Alzheimer: un análisis exploratório. Rev Esp Geriat. Gerontol [Internet]. 2008 [cited 2016 Jan 15];
43(5):308-15. Available from: http://www.elsevier. es/es-revista-revista-espanola-geriatria-gerontologia124-articulo-caracterizacion-los-grupos-ayudamutua-S0211139X0873573X_S300_es.pdf

9. Tristão FR, Santos SMA. Care of the elderly with Alzheimer's family caregiver: a university extension activity. Texto Contexto Enferm [Internet]. 2015 Dez [cited 2016 jan 15]; 24(4):1175-80. Available from: http:/ / www.scielo.br/scielo.php?script=sci_arttex t\&pid=S010407072015000401175\&lng=pt\&nrm= iso\&tlng $=p t$

10. Leininger MM. Culture care diversity and universality theory and evolution of the ethnonursing method. In: Leininger MM, Mcfarland MR. Culture care diversity and universality: a worldwide nursing theory. $2^{\mathrm{a}}$ ed. Massachusetts (US): Jones and Bartlett publishers; 2006.

11. Friese S. ATLAS.ti Scientific Software Development GmbH. [Internet] Berlin, 2003-2012; [cited 2015 jul 5]. Available from: http:/ / atlasti.com/manuals-docs

12. Bardin L. Análise de conteúdo. São Paulo (SP): Almedina Brasil; 2011.

13. Diel L, Forster LMK, Kochhann R, Chaves MLF. Sociodemographic profile and level of burden of dementia patients' caregivers who participate in a support group. Dement Neuropsychol [Internet]. 2010 [cited 2016 jan 15]; 4(3):232-7. Available from: http://www.demneuropsy.com.br/detalhe_artigo. asp?id=232

14. Gräbel E, Trilling A, Donath C, Luttenberger K. Support groups for dementia caregivers - predictors for utilization and expected quality from a family caregiver's point of view: a questionnaire survey PART I. BMC Health Serv Res [Internet]. 2010 [cited 2015 Nov 10]; 10:219. Available from: http:/ /www. biomedcentral.com/1472-6963/10/219

15. Wang L, Chien W, Lee IY. An experimental study on the effectiveness of a mutual support group for family caregivers of a relative with dementia in Mainland, China. Contemp Nurs [Internet]. 2012 [cited 2016 Jan 15]; 40(2):210-24. Available from: http:/ / www.tandfonline.com/doi/pdf/10.5172/ conu.2012.40.2.210?redirect $=1$

16. Ilha S, Zamberlan C, Piexak DR, Backes MTS, Dias MV, Backes DS. Contributions of a group about the Alzheimer's disease for family members/caregivers, professors and students from the healthcare field. Rev Enferm UFPE [Internet]. 2013 [cited 2015 Apr 6]; 7(5):1279-85. Available from: http://www.revista. ufpe.br/revistaenfermagem/index.php/revista/ article/download/3967/6034

17. Seebohm P, Chaudhary S, Boyce M, Elkan R, Avis M, Munn-Gidding C. The contribution of self-help/ mutual aid groups to mental well-being. Health Soc Care Community. 2013; 21(4):391-401.

18. Sena ELS, Meira EC, Souza AS, Santos ISC, Souza DM, Alvarez AM, et al. Tecnologia cuidativa de ajuda mútua grupal para pessoas com Parkinson e suas 
famílias. Texto Contexto Enferm [Internet]. 2010 JanMar [cited 2016 May 5]; 19(1): 93-103. Available from: http://www.scielo.br/pdf/tce/v19n1/v19n1a11

19. Valim MD, Damasceno DD, Abi-acl LC, Garcia F, Fava SMC. Doença de Alzheimer na visão do cuidador: um estudo de caso. Rev Eletr Enferm [Internet]. 2010 [cited 2016 Jan 16]; 12(3):528-34. Available from: https:// www.fen.ufg.br/fen_revista/v12/n3/v12n3a16.htm

20. Leme JB, Oliveira DC, Cruz KCT, Higa CMH, D'Elboux MJ. Grupo de apoio a cuidadores familiares de idosos: uma experiência bem sucedida. Cienc Cuid Saúde. 2011; 10(4):739-45.

21. Vieira L, Nobre JRS, Bastos CBC, Tavares KO. Cuidar de um familiar idoso dependente no domicílio: reflexões para os profissionais da saúde. Rev Bras Geriatr Gerontol. 2012; 15(2):255-64.
22. Ministério da Saúde (BR). Diretrizes para o cuidado das pessoas com doenças crônicas nas redes de atenção à saúde e nas linhas de cuidado prioritárias. Brasília (DF): MS; 2013.

23. Sena ELS, Gonçalves LHT, Granzotto MJM, Carvalho PAL, Reis HFT. Analítica da ambiguidade: estratégia metódica para a pesquisa fenomenológica em saúde.Rev Gaucha Enferm [Internet]. 2010 [cited 2015 Jun 5]; 31(4):769-75. Available from: http:/ / www.scielo.br/scielo.php?pid=S198314472010000400022\&script=sci_arttext

24. Santana AP, Santos SMA. Grupo de familiar/ cuidador de indivíduos com demências: práticas interdisciplinares. In: Berberian AP, Santana AP. Fonaudiologia em contexto grupais: referenciais teóricos e práticos. São Paulo (SP): Pexus; 2012. 